\title{
The Impact of the Business Environment on Young Firm Financing
}

\author{
Larry W. Chavis, Leora F. Klapper, and Inessa Love
}

\begin{abstract}
A unique dataset of over 70,000 firms, most of which are small, in over 100 countries, is utilized to systematically study the use of different financing sources for new and young firms. Consistent age-related patterns emerge. Across all countries younger firms rely less on bank financing and more on informal financing. There is a clear substitution effect: as firms mature, more firms switch out of informal finance toward bank finance, while the total proportion of firms using external finance remains relatively unchanged. Importantly, these relationships hold for firms of different sizes, firms in different sectors, and firms located in countries with different income levels and on different continents. Thus, these patterns of young firm financing show clear universal tendencies. Given that even small firms increasingly use formal bank financing over time, these results suggest that information asymmetry plays an important role in decreasing a young firm's ability to obtain bank finance. JEL codes: G2, G21, O16
\end{abstract}

Access to external finance and the ability to undertake profitable investment opportunities is an important ingredient for success of any new business and ultimately for economic development and growth (see Levine 2005). However, liquidity constraints hinder potential entrepreneurs from starting a business (see, for example, Evans and Jovanovic 1989) and reduce growth rates, especially in small businesses (Beck, Demirguc-Kunt, and Maksimovic 2004). Relaxing these constraints can promote new firm entry and success. For example, a cross-country study of 35 European countries finds that that entry is higher in more financially dependent industries in countries that have greater financial development (Klapper, Laeven, and Rajan 2006).

Larry W. Chavis (larry_chavis@unc.edu), assistant professor, Kenan-Flagler Business School, University of North Carolina at Chapel Hill, Leora F. Klapper (corresponding author, lklapper@ worldbank.org), lead economist, Development Research Group, The World Bank, Inessa Love (ilove@ worldbank.org), senior economist, Development Research Group, The World Bank. The authors thank the participants of the Kauffman Foundation Conference on Entrepreneurial Finance, the Cleveland Fed-Kauffman Foundation Conference on Entrepreneurial Finance, and The Second Annual Searle Center Research Symposium on the Economics and Law of the Entrepreneur and three anonymous referees for helpful comments. This paper was prepared with outstanding assistance from Douglas Randall. The opinions expressed do not necessarily represent the views of the World Bank, its Executive Directors or the countries they represent.

THE WORLD BANK ECONOMIC REVIEW, VOL. 25, NO. 3, pp. 486-507

doi:10.1093/wber/lhr045

(C) The Author 2011. Published by Oxford University Press on behalf of the International Bank for Reconstruction and Development / THE WORLD BANK. All rights reserved. For permissions, please e-mail: journals.permissions@oup.com 
Financing options of mature firms could be explained by the pecking order theory of financing (Myers and Majluf 1984). These firms generally have more internal funds (retained earnings) due to higher profitability and lower growth opportunities and, therefore, might prefer to use internal funds first (Bulan and Yan 2009; Brealey and Myers, 2003). Furthermore, a good reputation, such as a long credit history, mitigates the adverse selection problem between borrowers and lenders. Mature firms might therefore be able to obtain loans on better financial terms compared to their younger firm counterparts (Bulan and Yan 2009; Carpenter and Rondi 2000) and generally use debt before equity for their financing needs (Bulan and Yan 2009).

There is evidence from around the world that new firms without proven track records experience more severe financing constraints. For instance, studies conducted in China, Italy and the U.S. find that information asymmetry significantly limits the debt capacity of young firms (Shirai 2009; Bulan and Yan 2009; and Carpenter and Rondi 2000, respectively). In addition, higher financing constraints reduce the likelihood of starting a business in Thailand, especially in poorer regions (Paulson and Townsend 2004). In comparison, having an existing bank relationship increases the chances of starting a business with hired employees in Bosnia and improves the odds of survival for the new entrepreneur. Furthermore, according to studies of German and Canadian firms, a higher equity ratio in new firms has a particularly positive effect on investment in R\&D, while such an effect has not been found in older firms (Müller and Zimmermann 2006; Baldwin and others 2002).

Without access to formal financing, start-up firms might resort to informal sources. For example, family and friends provide affordable and accessible funding to Indian SME's in start-up and growth phases (Allen and others 2006). Yet financing from friends and family might be "unreliable, untimely" and bearing "significant non-financial costs" (Djankov and others 2002, p. 72). For instance, a study across 29 countries finds that firms choose informal financing over more formal routes when government officials are corrupt as a way to avoid paying bribes (Mehnaz and Wimpey 2007); thus firms might be willing to bear the costs of informal financing if there is the added benefit of evading corruption. A study of Chinese firms finds that while more firms use informal financing than bank financing, only bank financing is associated with higher growth rates (Ayyagari and others 2010).

To the best of our knowledge, there is no systematic cross-country study of the usage of financing by new and young firms. Our study attempts to fill this gap by examining a vast firm-level database constructed from 170 World Bank Enterprise Surveys (WBES). This database includes about 70,000 firms, most of which are small and medium sized (SMEs), in 104 developing and developed countries, including many low-income countries. ${ }^{1}$ This database is used to study what types of financing are important for new firms, relative to older

1. The complete questionnaire and database is available at http://www.enterprisesurveys.org/. 
firms, and explore rich cross-sectional variation in firm and country types. Our research addresses two questions: (1) What is the relationship between firm age and the use of external financing? and (2) Does this relationship hold for different types of firms and different groups of countries?

We start by investigating whether firms use any external finance or rely solely on internal funds and how age affects the use of external finance. Next, we examine the relationship between firm age and usage of different financing sources, including local and foreign bank financing, leasing, trade credit, credit cards, family and friends, and informal lenders. We focus on the use of formal versus informal finance over the lifecycle of firms, controlling for firm characteristics, such as sector and ownership.

We find that around the world younger firms use less formal (bank) finance and more informal finance, relative to older firms. Bank finance and informal finance serve as substitutes: as firms age, bank finance replaces informal finance, while the overall use of external finance remains relatively unchanged. Interestingly, these relationships between firm age and type of financing hold for firms of different sizes, firms in different industries, firms located in countries in different income groups and in different continents. Thus, the pattern of young firm financing appears universal. Our results also highlight that the likely reason for lower levels of bank finance in young firms is asymmetric information. Specifically, this follows from our finding that even smaller firms increase their reliance on bank finance (and decrease reliance on informal finance) as they get older and build a longer credit history. While indirectly, our results suggest that improving the availability and quality of credit information is important for alleviating financing constraints of young firms.

We consider firm age as a useful proxy for entrepreneurial firms. For example, Schumpeter wrote that a person is an entrepreneur "only when he actually carries out new combinations, and looses that character as soon as he has built up his business and settled into running it" (Schumpeter 1942). Thus, new and young firms are more likely to retain the "entrepreneurial spirit" alluded to by Schumpeter. Other useful proxies for an entrepreneur might be firms where an individual or family is the largest shareholder; whether the owner is also manager of the firm; and if the firm is registered as a sole-proprietor (relative to a limited-liability partnership or corporation.) In this paper we focus mainly on young firms as a proxy for 'entrepreneurial' firms, while also exploring other samples of firm ownership and legal types.

The rest of the paper is organized as follows: Section 2 presents our data. Section 3 presents our main results on the patterns of financing and firm age. Section 4 presents sample breakdowns by size, sector, income group and continent. Section 5 presents our results over time. Section 6 presents multivariate regression analysis. Section 7 concludes. 


\section{DATA}

The WBES dataset includes firms across multiple sectors (manufacturing, services, agriculture, and construction). The database includes both quantitative and qualitative information on firm characteristics, including sources of finance, barriers to growth, access to infrastructure services, legal difficulties, and corruption. The dataset also includes some measures of firm performance, such as multiple years of historical data on employment and sales.

The database includes over 70,000 randomly sampled firm-level observations collected in 170 cross-sectional surveys in 104 countries, i.e., many countries include multiple years of data. ${ }^{2}$ The database is globally represented, which we summarize by region: Sub-Saharan Africa (AFR), East Asia (EA), South Asia (SA), Eastern Europe and Central Asia (ECA), Latin America and Caribbean (LAC), and the Middle East and Northern Africa (MENA). The database also includes a few industrialized countries (IND). Figure 1 shows the distribution of countries and observations by region. A notable difference between the two panels is that surveys in Africa include a relatively small number of firm observations and fewer countries have multiple survey years, while surveys in East Asia include a relatively large number of firms and include multiple years. A complete list of countries and firm observations is shown in Appendix Table 1.

The distribution of firms across income groups highlights the uniqueness of our dataset (Figure 2). Unlike similar studies of entrepreneurial finance, which focus on firms in the U.S. or other developed countries, firms in our database are distributed across income groups, with a focus on developing countrieswhich are most likely to face barriers in the business environment. Our database includes 38 low-income and 37 lower-middle income countries, which account for over 73 percent of observations. The surveys were conducted over the span of eight years, 1999-2006 (Figure 2).

Figure 3 shows the distribution of firms in our sample across sectors, ownership, and output markets. We expect these firm characteristics to affect the use of external financing, relative to other young firms. A caveat is that some surveys focused exclusively on manufacturing companies, so in part by design, the majority of firms in our sample are manufacturing firms (60 percent), followed by services (30 percent) and construction ( 6 percent). Since manufacturing companies are likely to be more capital intensive, sources of entrepreneurial finance should be particularly illustrative of country-level barriers to access to credit. Next, we find 4 percent of firms with state ownership (particularly in lower income countries) and 5 percent with foreign ownership. Both types of firms might receive preferential access to financing. Finally, about

2. We are unable to control for whether an individual firm is included in multiple survey years, although the likelihood of a firm being included more than once is insignificant. 
Figure 1. Distributions of Surveyed Countries and Firm Observations by Region

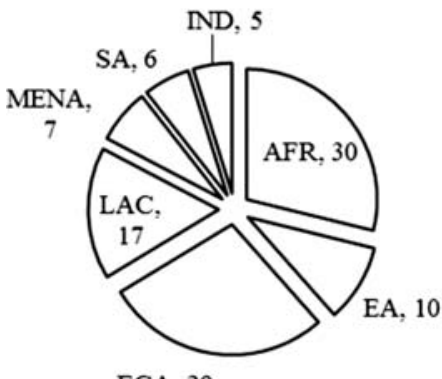

ECA, 29

Countries per region

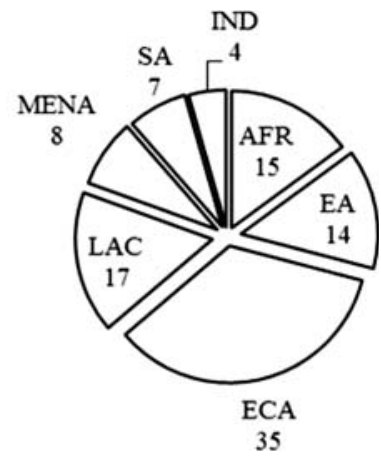

Observations (percent)

Source: Authors' analysis based on World Bank Enterprise Surveys.

Figure 2. Distribution of Total Firms, by Country-Level Income and Year
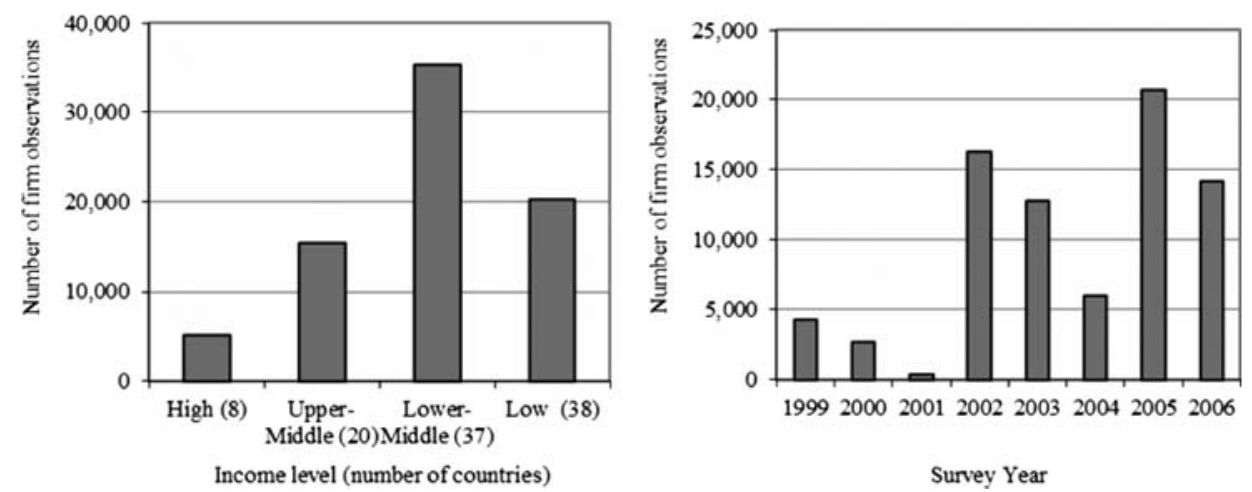

Source: Authors' analysis based on World Bank Enterprise Surveys.

23 percent of firms in our sample are identified as exporters, which might have greater access to overseas customer and bank financing.

Importantly for our analysis, the WBES data is a random sampling of firms. An important caveat, however, is that many country surveys do not include new firms: 79 percent of surveys have a minimum firm age of one; 8 percent a minimum firm age two; 4 percent a minimum firm age three, and 9 percent a minimum firm age four. ${ }^{3}$ Therefore, summary tables include an increasing number of country and firm observations along the age dimension. Figure 3 shows the distribution of total firms by age. Over 8 percent of the total sample is three years old or younger, while 58 percent of all firms are 12 years or

3. In robustness regressions, reported in section 5, we discuss our results using only surveys that include one year old firms, i.e., eliminating the sampling bias in some countries. 
Figure 3. Distribution of Firms by Sector, Ownership, Export Status and Age
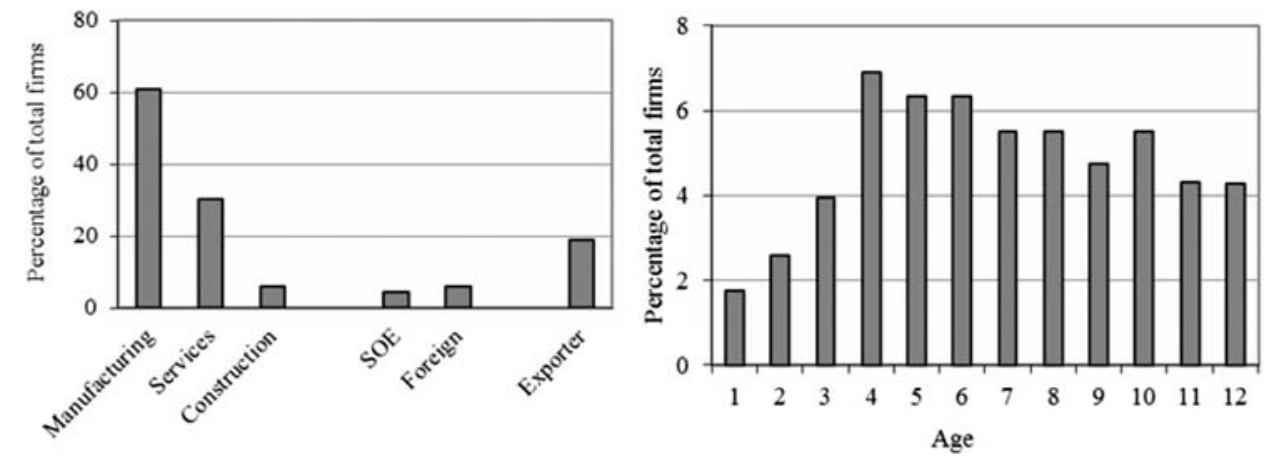

Source: Authors' analysis based on World Bank Enterprise Surveys.

younger. The largest number of observations is for age four, which includes observations from all country/year surveys, regardless of survey-specific minimum firm age.

\section{FinANCIAL PRODUCTS AND FIRM AGE}

We begin by examining whether age is related to the use of a bank line of credit $(\mathrm{L} / \mathrm{C})$ or overdraft facility. In our data, 44 percent of firms have a $\mathrm{L} / \mathrm{C}$, compared to 32 percent of firms that use bank financing to fund working capital or new investment; the correlation between a $\mathrm{L} / \mathrm{C}$ and bank financing is about 0.50 , and significant at 1 percent. $^{4}$ The usage of $\mathrm{L} / \mathrm{Cs}$ increases with firm age, from about 20 percent of new firms to over 40 percent of firms age six and older (Figure 4). This supports the hypothesis that access to bank and other sources of formal financing is related to firm age.

Next, we observe the complete distribution of sources for working capital and new investment financing, by age. The percentage of firms that use select types of financing for either working capital or new investment-disaggregated by financing source and aggregated by financing categories-are reported by firm age (Table 1). Throughout the paper we focus on five distinct categories of external financing sources: informal sources and family and friends ("Informal Finance"), foreign and domestic bank financing ("Bank Finance"), "Leasing," "Trade Credit," and "New Equity," which includes equity, grants, and other sources. ${ }^{5}$

4. Bank finance and L/C are analyzed separately because the data is drawn from two separate survey questions. Respondents are first asked which sources of financing they utilize (banks, leasing, trade credit, etc.) to fund working capital and new investment. They are then asked if their firm has a line of credit or overdraft facility.

5. We have also experimented with aggregating leasing and trade credit into one category that could be thought of as "operational finance," following Allen and others (2005) and Beck and others (2008). Our results were not materially affected and are available on request. We choose to report leasing and trade credit separately because leasing is asset-backed finance, while trade credit is largely "relationship based." 
Figure 4. Access to Letter of Credit by Firm Age

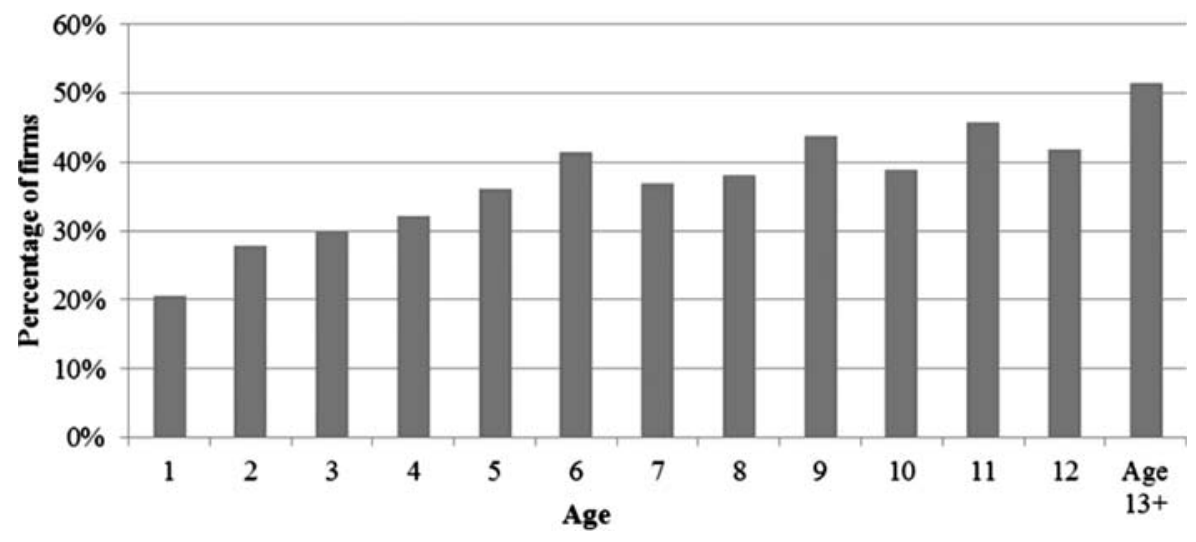

Source: Authors' analysis based on World Bank Enterprise Surveys.

The columns do not sum to 100 percent since most firms use more than one source of financing.

The percentage of firms using retained earnings is fairly consistent across our age categories. Similarly, there is no clear relationship between firm age and the use of new equity or trade credit. However, like the availability of a $\mathrm{L} / \mathrm{C}$, the use of both bank financing and leasing are more likely as firms mature. The relationship between age and informal financing runs in the opposite direction. Not only does the likelihood of using informal financing decrease over time, there is also a sharp decrease in this category-in both financing from friends and family and informal sources-during the first few years after a firm begins operations.

In addition, we construct an indicator variable called "no external financing," which is equal to one if the firm does not use any external sources of financing. This measure has somewhat of an inverted U-shape-it is low for very young firms, higher for firms aged 3-8 years, and then drops for older firms. We speculate that start-up firms need to rely more on external financealthough in emerging markets, this financing is mostly from informal sources, which is significantly higher in the first two years of firm life than in subsequent years. As firms mature, they are more likely to use formal sources of external finance (and therefore less likely to be classified into the "no external finance" category).

Table 2 shows the percentage of total Working Capital (Panel A) and New Investment (Panel B) financing provided by each type of financing (the columns do not sum to 100 percent because credit cards are excluded). The primary source of working capital financing for all firm ages is retained earnings. In other words, on average, firms in all size buckets rely primarily on their own funds for over half of their financing needs, which is in line with the pecking 
Table 1. Financing Patterns (Working Capital or New Investment) by Firm Age (percent)

\begin{tabular}{lrrrrrrrr}
\hline & $1-2$ & $3-4$ & $5-6$ & $7-8$ & $9-10$ & $11-12$ & $13+$ & Total \\
\hline Retained Earnings & 85 & \multicolumn{7}{c}{ Panel A: By Financing Type } \\
Local Banks & 17 & 20 & 25 & 85 & 85 & 86 & 83 & 84 \\
Foreign Banks & 2 & 2 & 2 & 5 & 27 & 31 & 37 & 30 \\
Leasing & 3 & 5 & 7 & 6 & 7 & 2 & 4 & 3 \\
Trade Credit & 30 & 22 & 27 & 21 & 29 & 26 & 29 & 7 \\
Credit Cards & 1 & 2 & 2 & 2 & 2 & 3 & 2 & 2 \\
Family \& Friends & 22 & 15 & 14 & 13 & 14 & 10 & 9 & 12 \\
Informal Sources & 10 & 7 & 4 & 4 & 3 & 3 & 3 & 4 \\
Grants & 3 & 2 & 3 & 3 & 3 & 3 & 4 & 3 \\
Equity & 10 & 10 & 10 & 10 & 10 & 10 & 10 & 10 \\
Other & 4 & 6 & 8 & 7 & 7 & 5 & 9 & 7 \\
& & & Panel B: By Financing Category & & & \\
Bank Financing & 18 & 21 & 26 & 29 & 31 & 32 & 39 & 32 \\
Leasing & 3 & 5 & 7 & 6 & 7 & 8 & 7 & 7 \\
Trade Credit & 30 & 22 & 27 & 21 & 29 & 26 & 29 & 27 \\
Informal Finance & 31 & 20 & 16 & 15 & 16 & 12 & 10 & 14 \\
New Equity & 15 & 17 & 19 & 18 & 18 & 17 & 21 & 19 \\
No External Finance & 38 & 45 & 43 & 44 & 36 & 39 & 35 & 39 \\
\hline
\end{tabular}

Note: Panel A shows the percentage of firms that use the financing source for either Working Capital or New Investment (i.e., the reported percentage of total financing is greater than zero). Panel B shows the percentage of firms that use the financing source, by aggregated categories: "Bank Finance" includes local and foreign banks, "Leasing," "Trade Credit," "Informal Finance," which includes family and friends and informal sources, and "New Equity" includes equity, grants, and other sources.

Source: Authors' analysis based on World Bank Enterprise Surveys.

order theory of capital structure. However, the reliance on different types of external financing shows a monotonic relationship with age: for instance, older firms use a larger percentage of bank finance and leasing and rely less on informal sources. As firms mature, they might shift their dependence from informal sources of finance to more formal sources. ${ }^{6}$ Trade credit is also an important source of working capital financing for all firms, and becomes slightly more important as firms get older-and establish longer relationships with their suppliers. Young firms are more likely to receive infusions of new equity capital, relative to older firms; however, these are likely to be the owner's own funds.

Summary statistics of loan characteristics are shown in Table 3. There is not a notable difference between the use of collateral, the percentage of loan size collateralized, interest rates, or maturity across firm age. However, new firms are less likely to have audited accounts.

Table 4 shows summary statistics of the variables used in our econometric specifications. Panel A shows summary statistics of all firms. (Complete

6. In addition, firms with access to formal financing may be more likely to survive (to an older age). 
Table 2. Distribution of Firm Financing by Firm Age (percent)

\begin{tabular}{lrrrrrrrr}
\hline & $1-2$ & $3-4$ & $5-6$ & $7-8$ & $9-10$ & $11-12$ & $13+$ & Total \\
\hline Retained Earnings & 61 & 68 & \multicolumn{7}{c}{ Panel A: Working Capital } & & & \\
Bank Financing & 9 & 8 & 10 & 11 & 11 & 11 & 16 & 13 \\
Leasing & 0 & 1 & 1 & 1 & 1 & 1 & 1 & 1 \\
Trade Credit & 12 & 7 & 11 & 8 & 9 & 9 & 11 & 10 \\
Informal Finance & 8 & 7 & 6 & 5 & 5 & 4 & 3 & 5 \\
New Equity & 9 & 9 & 9 & 9 & 9 & 8 & 9 & 9 \\
Retained Earnings & 66 & 66 & 65 & 66 & 62 & 64 & 59 & 62 \\
Bank Financing & 9 & 10 & 12 & 13 & 16 & 17 & 20 & 16 \\
Leasing & 1 & 2 & 3 & 2 & 3 & 3 & 3 & 3 \\
Trade Credit & 3 & 3 & 5 & 3 & 4 & 3 & 3 & 3 \\
Informal Finance & 10 & 9 & 5 & 4 & 4 & 3 & 3 & 5 \\
New Equity & 10 & 10 & 10 & 10 & 10 & 8 & 11 & 10 \\
\hline
\end{tabular}

Note: This table shows the percentage of total Working Capital (Panel A) or New Investment (Panel B) financing provided by each of these sources. "Bank Finance" includes local and foreign banks; "Leasing," "Trade Credit," "Informal Finance," which includes family and friends and informal sources, and "New Equity" includes equity, grants, and other sources. Columns do not sum to 100 percent as credit cards are excluded.

Source: Authors' analysis based on World Bank Enterprise Surveys.

Table 3. Summary Statistics of Loan Characteristics by Firm Age

\begin{tabular}{lllllllll}
\hline & $1-2$ & $3-4$ & $5-6$ & $7-8$ & $9-10$ & 12 & $13+$ & Total \\
\hline Loan requires collateral (percent) & 76 & 77 & 78 & 73 & 81 & 80 & 75 & 76 \\
$\begin{array}{l}\text { Value of collateral, relative to loan } \\
\quad 129\end{array}$ & 132 & 193 & 130 & 131 & 138 & 138 & 141 \\
$\quad$ value (percent) & 13 & 14 & 15 & 13 & 14 & 14 & 13 & 13 \\
$\begin{array}{l}\text { Interest rate (percent) } \\
\text { Loan duration (months) }\end{array}$ & 34.7 & 33.2 & 32.2 & 35.2 & 31.5 & 32.3 & 36.2 & 34.5 \\
$\begin{array}{l}\text { Audited financial statements } \\
\quad \text { (percent) }\end{array}$ & 42 & 37 & 43 & 52 & 54 & 50 & 61 & 53 \\
\hline
\end{tabular}

Source: Authors' analysis based on World Bank Enterprise Surveys.

variable definitions are shown in Appendix 2). The average firm age in our sample is 15 years, with a maximum age capped at 80 years. 27 percent of firms are identified as "Micro," with less than 10 employees; 39 percent are identified as "Small," with less than 50 employees; and the remaining firms as "Medium/Large." In our sample 23 percent of firms are exporters, 48 percent are corporations, and 52 percent have audited statements. Finally, 4 percent of firms are identified as state-owned and 5 percent as foreign-owned.

Panel B shows mean tests between characteristics of firms that use external finance versus firms that use only retained earnings. Older and larger firms are more likely to use external finance; limited liability companies (LLCs) are significantly more likely to use external finance than other types (e.g., sole 
Table 4. Summary Statistics and Mean Tests by Category

\begin{tabular}{|c|c|c|c|c|c|c|}
\hline & \multicolumn{2}{|c|}{ Panel A: All Firms } & \multicolumn{2}{|c|}{$\begin{array}{l}\text { Panel B: Comparing Firms With and Without } \\
\text { Financing }\end{array}$} & \multicolumn{2}{|c|}{$\begin{array}{c}\text { Panel C: Comparing Firms by } \\
\text { Age }\end{array}$} \\
\hline & Mean & Obs. & No External Financing & Uses External Financing & Firm age $\leq 5$ & Firm age $>5$ \\
\hline Firm Age (years) (percentage of firms) & 15.9 & 68,419 & 14.8 & $16.6 * * *$ & 3.6 & $19.4 * * *$ \\
\hline Micro & 27 & 62,900 & 36 & $22 * * *$ & 44 & $23 * * *$ \\
\hline Small & 39 & 62,900 & 38 & $39 * *$ & 35 & $40 * * *$ \\
\hline Medium/Large & 34 & 62,900 & 26 & $39 * * *$ & 21 & $37 * * *$ \\
\hline Limited Liability Company & 48 & 66,701 & 38 & $54 * * *$ & 40 & $50 * * *$ \\
\hline Sole Proprietorship & 27 & 66,701 & 33 & $22 * * *$ & 38 & $23 * * *$ \\
\hline Owner Manager & 32 & 68,419 & 35 & $31 * * *$ & 32 & 32 \\
\hline Exporter & 23 & 67,480 & 18 & $26 * * *$ & 16 & $25 * * *$ \\
\hline Audit & 52 & 67,453 & 45 & $56 * *$ & 39 & $55 * *$ \\
\hline Foreign Owned & 5 & 68,419 & 5 & $6^{*}$ & 4 & $6 * * *$ \\
\hline State Owned & 4 & 68,419 & 4 & $3 * *$ & 1 & $4 * * *$ \\
\hline
\end{tabular}

Note: Complete variable descriptions are shown in Appendix 2. Panels A and B shows summary statistics for all firms that report financing sources. Panel C shows summary statistics for firms that are (i) less than or equal to five years old and (ii) greater than five years old. The second column in Panels $\mathrm{B}$ and $\mathrm{C}$ shows t-statistics for mean difference. This compares firms with and without financing in Panel B and firms more or less than five years old in Panel C. Asterisks *,**, and $* *$ indicate significance at 10 percent, 5 percent, and 1 percent, respectively.

Source: Authors' analysis based on World Bank Enterprise Surveys. 
proprietorships and partnerships); while firms run by owner-managers are less likely to use external finance (possibly because they rely more on the owner's own funds). Exporting and foreign owned firms are more likely to use external finance, as are those with audited financial statements.

Panel C shows summary statistics and mean tests disaggregated by firms (i) less than or equal to five years old, and (ii) firms older than five years. These preliminary statistics show large and significant differences between younger and older firms. For instance, young firms are almost twice as likely to be micro (defined as less than 10 employees) and significantly less likely to be exporters or to have audited financial statements.

\section{BREAKDOWN BY GNI, REgION, FIRM SIZE, AND SECTOR}

In this section, we consider how the patterns described above vary across firms operating in countries with different levels of economic development (measured by income level) and across regions, and the relationship with firm size and sector. We begin with income groups. Figure 5 shows the patterns of bank finance, informal finance, and leasing. Across income groups, the patterns appear similar for these three key measures. Bank financing (Figure 5) increases with age in all groups-almost doubling by the time a firm reaches 13 years of age, relative to new firms - and is highest (for all ages) in high income countries. The use of informal finance (Figure 5) declines with age across all income groups, and it is highest in lower-income countries across all age groups.

The percentage of firms using leasing finance is significantly larger in countries with middle-high and high income (Figure 5). Leasing finance is a more sophisticated type of finance and is rarely available in lower income countries. In high income countries there is a clear positive relationship between leasing and age. The use of trade credit (not shown) does not seem to be systematically related to income.

Our measure of "no external financing" does not show significant changes over the life of the firm (not shown). The relatively stable proportion of firms with no external finance is likely be explained by substitution between bank finance and informal finance-as firms mature they may switch from one source to another, while their reliance on external finance does not change dramatically over the life cycle. (Later we show a more formal empirical test for whether this relationship is statistically significant in a multivariate framework).

We also consider whether there are regional variations in bank finance and informal finance using World Bank Country classifications for the sample of developing countries (Figure 6). Similar patterns emerge in all regions-an increasing use of bank finance with age and a declining use of informal finance with age. Again, there are no strong patterns for our "no external finance" measure (not reported).

Next, we present the relationship between age and sources of financing for firms of varying sizes. For every age level, smaller firms use less bank finance 
Figure 5. Financing Patterns by Income Groups
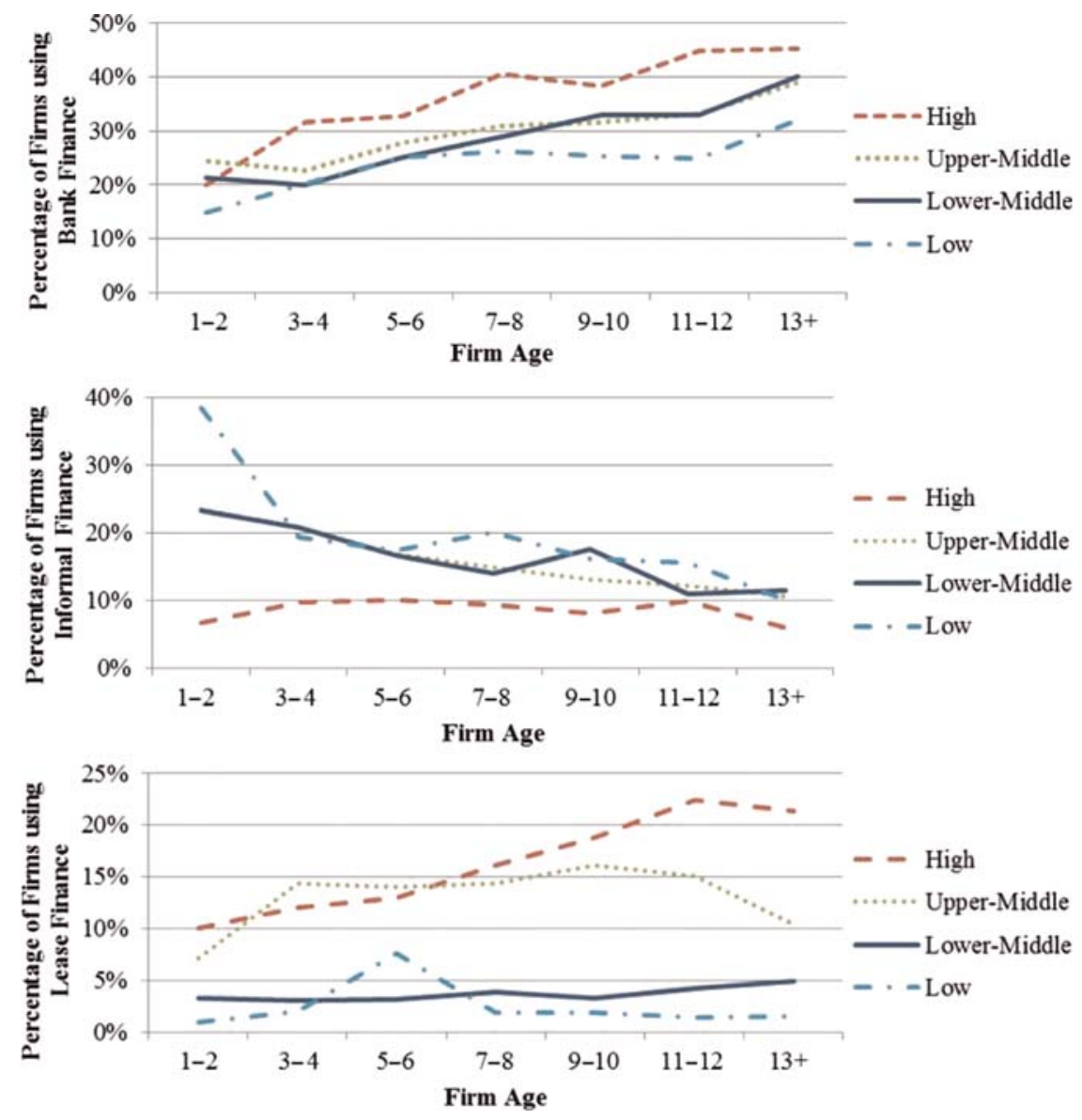

Source: Authors' analysis based on World Bank Enterprise Surveys.

and more informal finance than larger firms (Figure 7). In fact, the lines for micro, small, and medium/large firms are almost parallel (and upward slopping). These patterns are consistent with stylized facts in the literature on the difference between firm sizes and their usage of bank finance (Beck, Demirguc-Kunt, and Maksimovic 2008).

While banking financing increases, informal finance gradually declines for all firm sizes (Figure 7). The fact that even small firms use more bank finance as they age points to informational asymmetries as an important reason for lack of finance for younger firms, for example, firms can build positive credit histories over time. There is no strong pattern between the category "no external finance" and firm age, however, smaller firms use less external finance for all age groups (not shown). 
Figure 6. Financing Sources by Region

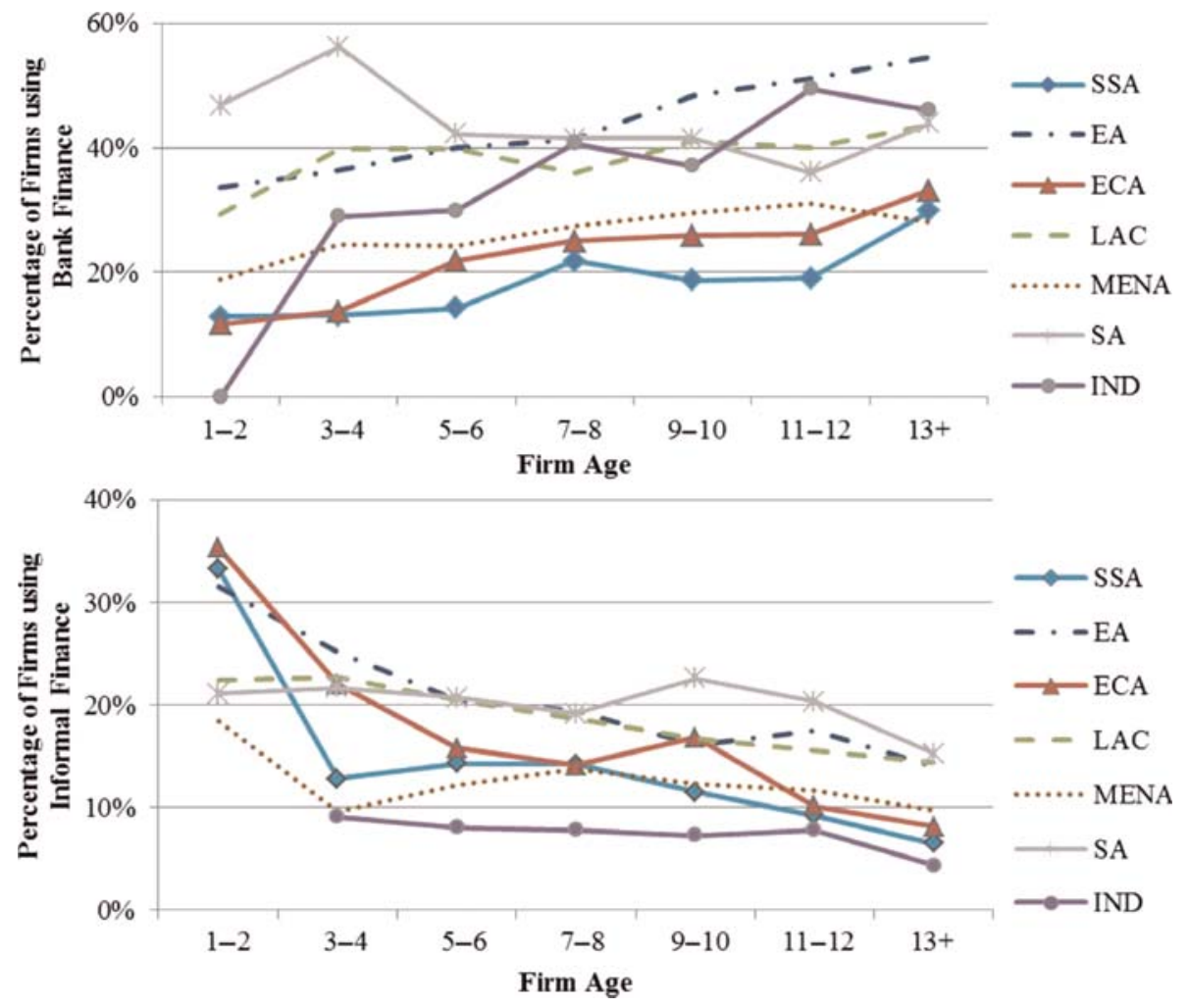

Source: Authors' analysis based on World Bank Enterprise Surveys.

Finally, in regard to sectoral differences, bank finance is increasing and informal finance is declining in all four sectors. Firms in the manufacturing sector are most likely to use bank finance and firms in the service sector are least likely to do so (Figure 8 ). This is possibly because of collateral requirements-service firms are less likely to have any significant fixed assets to use as collateral. Service firms also use the most informal finance, especially in their early years (Figure 8 ). There are no significant differences across sectors in the use of external finance (not shown).

To summarize, our findings suggests that bank finance increases with firm age and informal finance declines with firm age for all groups of firms and countries in our sample.

\section{FinANCING PATtERnS OVER TIME}

To study the relationship over time, we examine a sample of countries with surveys in multiple years. For a subset of 22 countries in Europe, we have three 
Figure 7. Financing Sources by Size
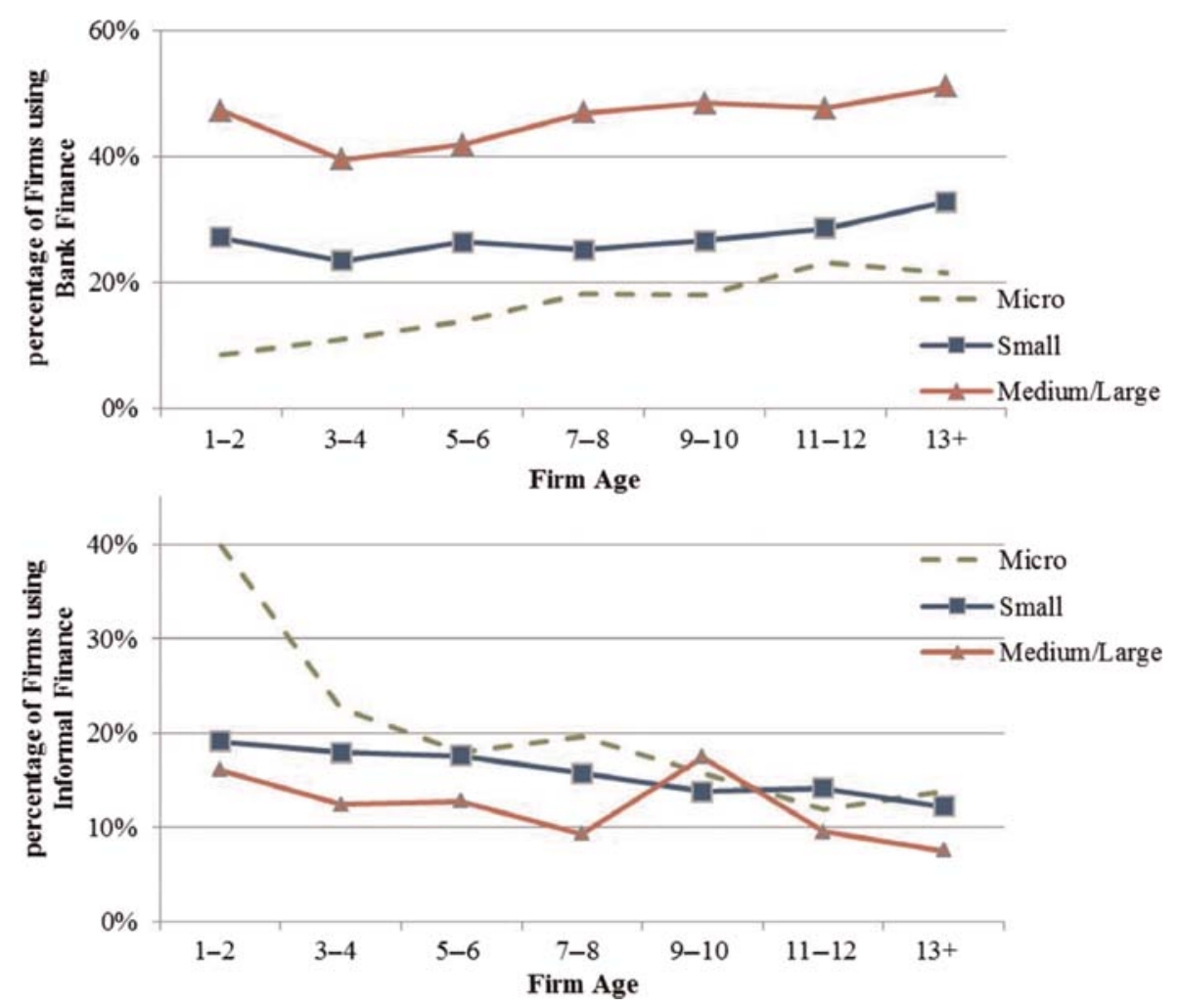

Source: Authors' analysis based on World Bank Enterprise Surveys.

repeated surveys: in 1999, 2002 and $2005 .^{7}$ We show the average of each main source of financing and the "no external finance" indicator over these three repeated cross-sections. Among this group of countries, bank finance was the lowest in 2002, and the highest in 2005 (Table 5). Leasing and trade credit do not show changes over time, while the use of informal finance decreased over this time frame from about 20 percent of all firms using informal finance in 1999 to about 13 percent in 2005. These patterns reflect the increasing use of formal financing by these firms, and, in parallel, the declining reliance on informal finance. The proportion of firms without any external finance is higher in 2002 and 2005 relative to 1999 . The previously outlined trend of the use of banking increasing with firm age while the use of informal financing decreases continues to hold in this sample (Figure 9). An important caveat to this analysis is that this is not a panel of identical firms, but rather repeated cross-sections. Therefore, the sample composition may affect these results.

7. This is the sample of Business Environment and Enterprise Performance Surveys (BEEPS), which is a joint initiative of the European Bank for Reconstruction and Development (EBRD) and the World Bank Group. 
FiguRE 8. Financing Sources by Sector
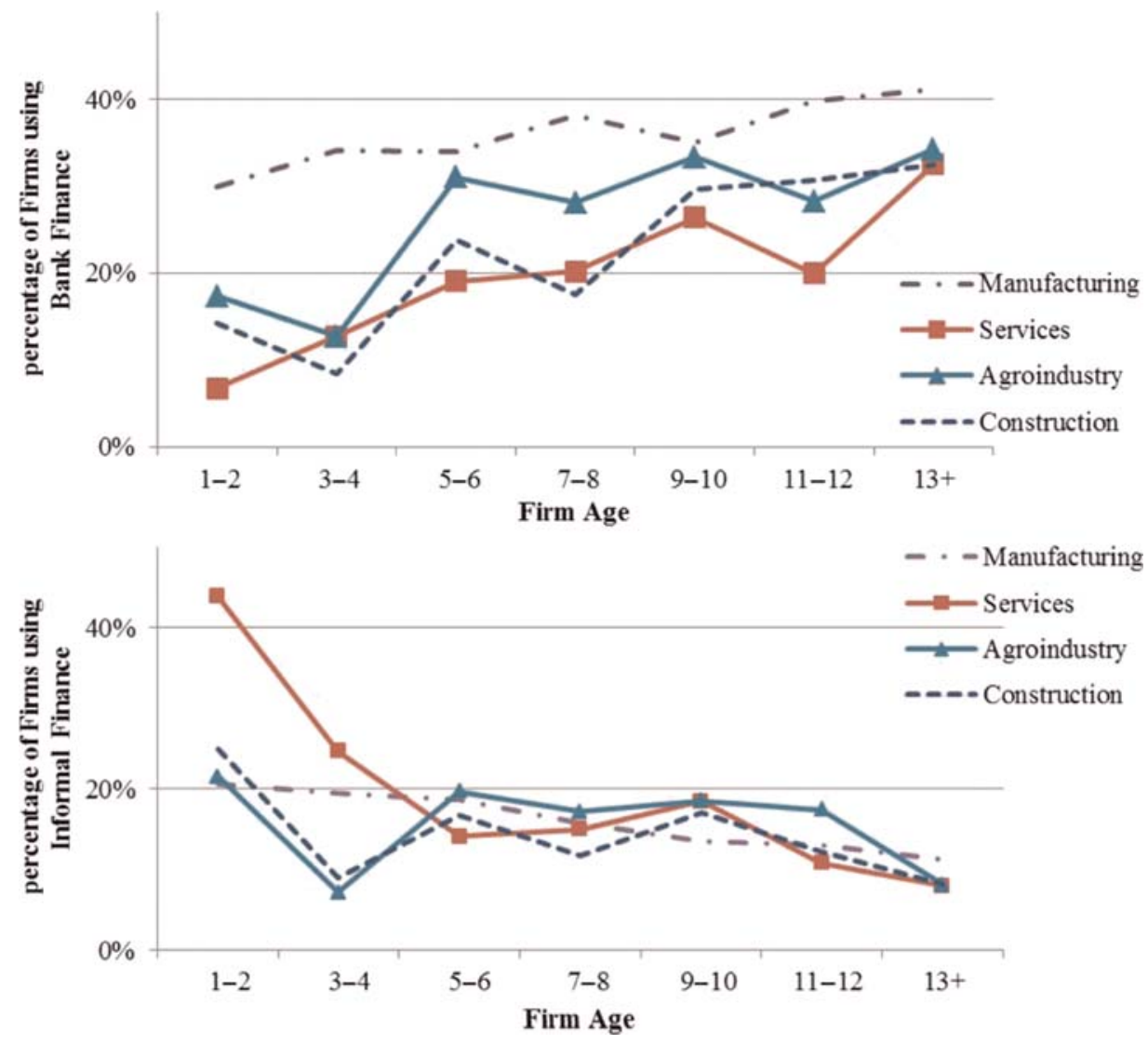

Source: Authors' analysis based on World Bank Enterprise Surveys.

Table 5. Financing Patterns Over Time (percent)

\begin{tabular}{lccccc}
\hline Survey Year & Banking & Leasing & Trade Credit & Informal & No External Financing \\
\hline 1999 & 24.9 & 12.7 & 16.5 & 19.9 & 40.4 \\
2002 & 19.2 & 11.5 & 20.0 & 18.0 & 45.4 \\
2005 & 32.2 & 11.6 & 14.8 & 13.3 & 46.6 \\
\hline
\end{tabular}

Note: Table shows the percentage of firms that use each financing source for either Working Capital or New Investment by aggregated categories: "Bank Finance" includes local and foreign banks; "Leasing"; "Trade Credit"; "Informal Finance," which includes family and friends and informal sources; and "New Equity" includes equity, grants, and other sources. This is based on the 22 European countries for which surveys were carried out in three separate years.

Source: Authors' analysis based on World Bank Enterprise Surveys.

In addition, we investigate whether there was "mean-reversion" over time. Countries that fell below average in the usage of bank finance in the earlier part of the sample experienced faster growth in bank finance (Figure 10). This 
Figure 9. Financing Patterns Over Time
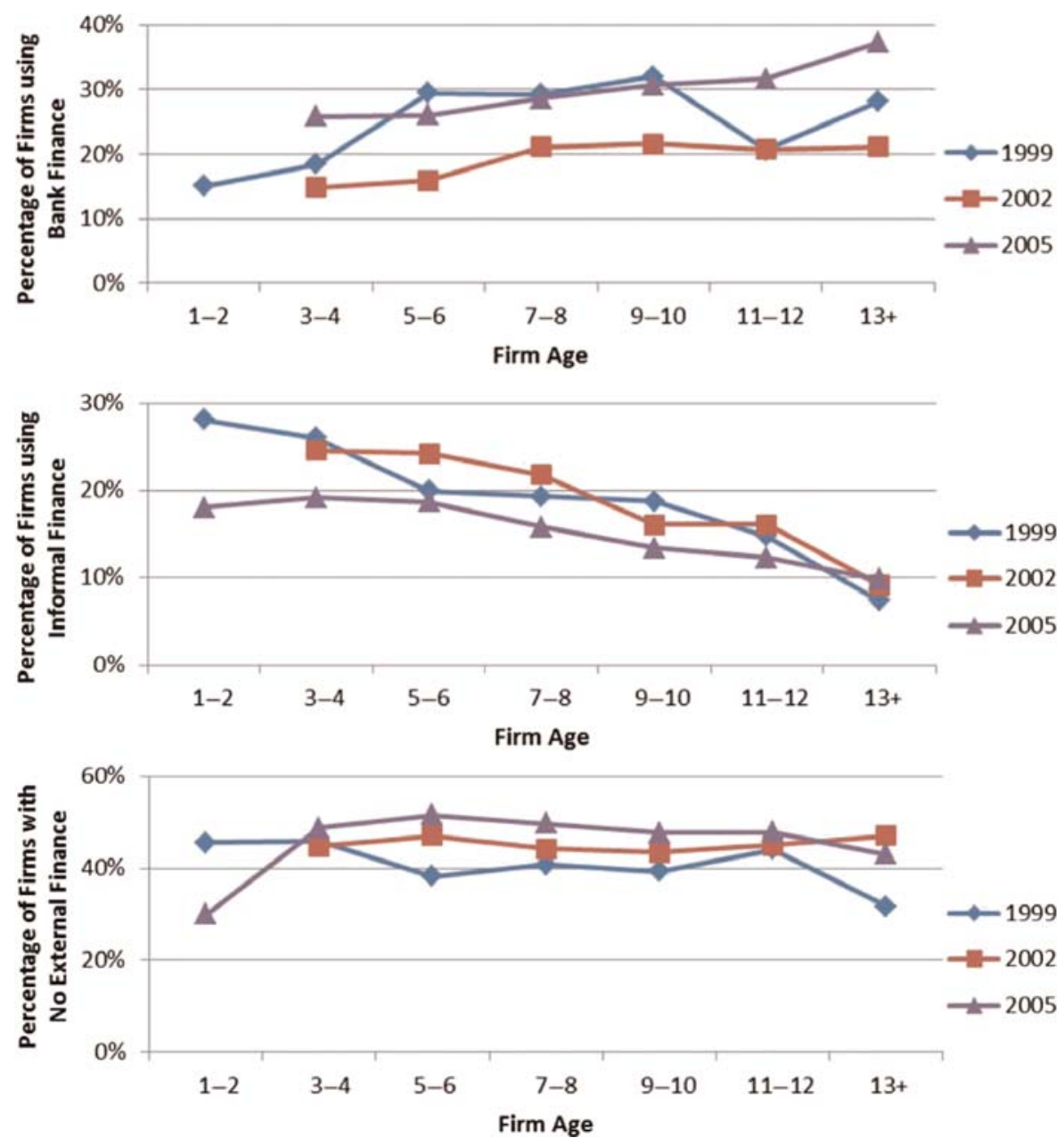

Source: Authors' analysis based on World Bank Enterprise Surveys.

relationship is even more significant with regards to informal finance (Figure 10). Thus, countries with the highest usage of informal finance in 1999 experienced the largest declines in the use of informal finance (i.e., a negative change). Similar patterns occur for "no external finance" measures (Figure 10). These graphs show a convergence in financing indicators over time and less variation in these measures in the later part of the sample than in the earlier years.

\section{Multivariate regression analysis}

In this section we investigate the relationship between our four main categories of external finance and age using a simple multivariate regression framework. 
Figure 10. Mean Reversion in Financing Patterns Over Time
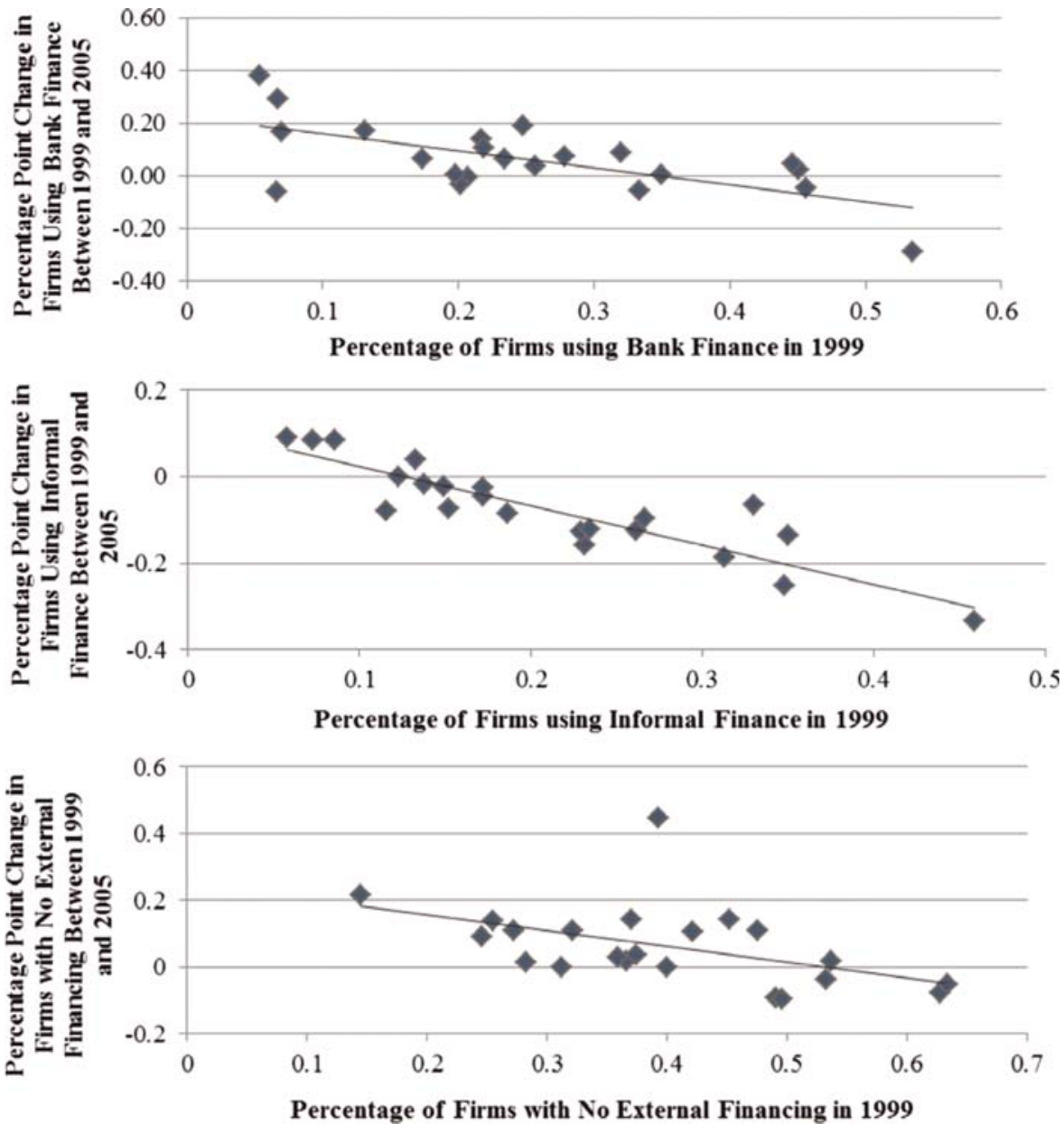

Source: Authors' analysis based on World Bank Enterprise Surveys.

While we cannot claim causality, this analysis serves to verify the patterns observed earlier, while controlling for different sample compositions across countries.

Table 6 reports regressions for each of the sources of finance defined above: bank finance, leasing, trade credit, and informal finance. In this table, the dependent variables are equal to one if the firm uses a type of financing for either working capital or new investment, and zero otherwise. In addition, we include a dummy which is equal to one if a firm uses a line of credit or overdraft facility. We estimate the model by probit with standard errors clustered by country and year (because several countries have more than one survey). In our main regressions (columns 1-5), we exclude firms that use zero external financing, since we are unable to disentangle whether these firms rely on 
Table 6. Is There a Relationship between Sources of Finance and Firm Age?

\begin{tabular}{|c|c|c|c|c|c|c|}
\hline & $\begin{array}{c}(1) \\
\text { Line of Credit }\end{array}$ & $\begin{array}{c}(2) \\
\text { Bank Finance }\end{array}$ & $\begin{array}{c}(3) \\
\text { Leasing }\end{array}$ & $\begin{array}{c}(4) \\
\text { Trade Credit }\end{array}$ & $\begin{array}{c}(5) \\
\text { Informal Finance }\end{array}$ & $\begin{array}{c}(6) \\
\text { No External Financing }\end{array}$ \\
\hline Ln Firm Age & $\begin{array}{l}0.039 \\
{[0.00] * * *}\end{array}$ & $\begin{array}{l}0.041 \\
{[0.01]^{* * * *}}\end{array}$ & $\begin{array}{r}-0.001 \\
{[0.74]}\end{array}$ & $\begin{array}{c}0.017 \\
{[0.07]^{*}}\end{array}$ & $\begin{array}{l}-0.054 \\
{[0.00]^{* * *}}\end{array}$ & $\begin{array}{r}-0.012 \\
{[0.16]}\end{array}$ \\
\hline Micro & $\begin{array}{l}-0.258 \\
{[0.00] * * *}\end{array}$ & $\begin{array}{l}-0.230 \\
{[0.00]^{* * *}}\end{array}$ & $\begin{array}{l}-0.051 \\
{[0.00]^{*} * *}\end{array}$ & $\begin{array}{l}-0.081 \\
{[0.00]^{* * *}}\end{array}$ & $\begin{array}{l}0.163 \\
{[0.00]^{* * *}}\end{array}$ & $\begin{array}{l}0.179 \\
{[0.00]^{* * *}}\end{array}$ \\
\hline Small & $\begin{array}{l}-0.173 \\
{[0.00] * * *}\end{array}$ & $\begin{array}{l}-0.150 \\
{[0.00]^{* * *}}\end{array}$ & $\begin{array}{l}-0.025 \\
{[0.00]^{*} * *}\end{array}$ & $\begin{array}{r}-0.003 \\
{[0.90]}\end{array}$ & $\begin{array}{l}0.059 \\
{[0.01]^{* * *}}\end{array}$ & $\begin{array}{l}0.067 \\
{[0.00]^{* * *}}\end{array}$ \\
\hline Limited Liability & $\begin{array}{l}0.050 \\
{[0.02]^{* *}}\end{array}$ & $\begin{array}{l}0.045 \\
{[0.01]^{* * *}}\end{array}$ & $\begin{array}{r}0.010 \\
{[0.15]}\end{array}$ & $\begin{array}{r}0.013 \\
{[0.57]}\end{array}$ & $\begin{array}{l}-0.036 \\
{[0.01]^{* *}}\end{array}$ & $\begin{array}{l}-0.083 \\
{[0.00]^{* * *}}\end{array}$ \\
\hline Exporter & $\begin{array}{l}0.045 \\
{[0.00]^{* * *}}\end{array}$ & $\begin{array}{c}0.030 \\
{[0.08]^{*}}\end{array}$ & $\begin{array}{r}0.005 \\
{[0.23]}\end{array}$ & $\begin{array}{r}0.014 \\
{[0.64]}\end{array}$ & $\begin{array}{r}-0.018 \\
{[0.17]}\end{array}$ & $\begin{array}{r}-0.009 \\
{[0.59]}\end{array}$ \\
\hline Audit & $\begin{array}{l}0.088 \\
{[0.00]^{* * *}}\end{array}$ & $\begin{array}{l}0.050 \\
{[0.02]^{*} *}\end{array}$ & $\begin{array}{c}0.009 \\
{[0.08]^{*}}\end{array}$ & $\begin{array}{r}0.000 \\
{[0.98]}\end{array}$ & $\begin{array}{l}-0.027 \\
{[0.04]^{* *}}\end{array}$ & $\begin{array}{l}-0.050 \\
{[0.00]^{*} *}\end{array}$ \\
\hline Foreign Owned & $\begin{array}{r}-0.008 \\
{[0.82]}\end{array}$ & $\begin{array}{r}0.043 \\
{[0.54]}\end{array}$ & $\begin{array}{c}-0.011 \\
{[0.06]^{*}}\end{array}$ & $\begin{array}{r}0.069 \\
{[0.49]}\end{array}$ & $\begin{array}{l}-0.142 \\
{[0.00]^{* * *}}\end{array}$ & $\begin{array}{r}0.014 \\
{[0.76]}\end{array}$ \\
\hline State Owned & $\begin{array}{r}-0.016 \\
{[0.81]}\end{array}$ & $\begin{array}{l}-0.167 \\
{[0.00]^{* * *}}\end{array}$ & $\begin{array}{l}-0.036 \\
{[0.00] * *}\end{array}$ & $\begin{array}{r}-0.012 \\
{[0.66]}\end{array}$ & $\begin{array}{l}-0.118 \\
{[0.00] * * *}\end{array}$ & $\begin{array}{c}0.063 \\
{[0.05]^{*}}\end{array}$ \\
\hline Observations & 37,434 & 37,083 & 27,485 & 37,049 & 37,061 & 58,771 \\
\hline Censored Obs. (percent) & 43.80 & 51.10 & 13.40 & 43.90 & 21.90 & 38.90 \\
\hline Pseudo $\mathrm{R}^{2}$ & 0.27 & 0.19 & 0.21 & 0.2 & 0.14 & 0.12 \\
\hline
\end{tabular}

Note: Table 6 reports probit estimates with country fixed effects. The dependent variable in the first column is a dummy equal to one if the firm reports using a line of credit or overdraft facility; the second column is a dummy equal to one if the firm uses local or foreign bank financing ("Bank Finance"), the third column is a dummy equal to one if the firm uses leasing; the fourth column is a dummy equal to one if the firm uses trade credit, and the fifth column is a dummy equal to one if the firm uses informal financing. We exclude firms that do not use any source of external finance (i.e., retained earnings equals 100 percent). All variables are defined in Appendix 2. All regressions include sector fixed effects (manufacturing, services, and construction), country-level fixed-effects, and survey year fixed effects. P-values based on standard errors clustered by country and survey year are reported. Asterisks $*, * *$, and $* *$ indicate significance at 10 percent, 5 percent, and 1 percent respectively.

Source: Authors' analysis based on World Bank Enterprise Surveys. 
internal financing by choice or because they have been rejected by external creditors. However, in column 6 we present regressions for our "no external financing" indicator to test whether there is a significant relationship with age and other controls.

The regressions control for a number of firm characteristics, such as dummies indicating micro and small sized firms (medium/large firms are the omitted category), exporters, firms with audited statements, legal status (limited liability vs. other types), and state and foreign ownership. We also include dummies for sector fixed effects (manufacturing, services, and construction), country-level fixed effects, and survey year. The key variable of interest is the log of firm age.

The results are similar to the univariate results discussed before: bank finance is gradually increasing with age, while informal finance is gradually decreasing with age. The usage of L/Cs follows a similar increasing trend over the life of the firm. We do not find a significant pattern for leasing finance, though trade credit use is slightly increasing with age (and the likely length of supplier relationships). We also observe a negative, but not statistically significant, relationship between firm age and the use of external finance, which is similar to the graphical analysis presented earlier.

The multivariate regressions show that the descriptive results discussed earlier are not driven by different composition of firms across countries, or different country-level characteristics (which are captured by firm-level control variables and country dummies). However, these regressions simply show partial correlation and do not attempt to establish causality of firm age and access to external finance or types of finance, which is a limitation of our dataset.

\section{CONCLUSIONS}

In this paper, we systematically study the use of different financing sources for new and young firms. We use a unique dataset from over 170 surveys, which contain about 70,000 firms, most of which are small and medium sized (SMEs) in 104 developing and developed countries, including many low-income countries. We use this dataset to examine corporate financing decisions, focusing on the relationship between firm age and sources of external financing.

Across all countries, younger firms have less reliance on bank financing and more reliance on informal financing. The relationship with leasing and trade credit is less associated with firm age. This relationship holds for firms of different sizes, firms in different industries, and firms located in countries in different continents and different income groups. Over time, countries tend to converge; that is, countries with low bank financing increase reliance on bank financing faster than countries with initial higher levels of bank finance. 
APPENDIX

Table A1. List of Countries and Number of Observations

\begin{tabular}{|c|c|c|c|c|c|}
\hline Albania & 537 & Germany & 1,196 & Nepal & 223 \\
\hline Algeria & 557 & Greece & 546 & Nicaragua & 452 \\
\hline Angola & 540 & Guatemala & 455 & Niger & 125 \\
\hline Argentina & 1,063 & Guinea & 327 & Nigeria & 232 \\
\hline Armenia & 647 & Guinea-Bissau & 296 & Oman & 337 \\
\hline Azerbaijan & 657 & Guyana & 163 & Pakistan & 965 \\
\hline Bangladesh & 1,001 & Honduras & 450 & Panama & 604 \\
\hline Belarus & 707 & Hungary & 1,007 & Paraguay & 613 \\
\hline Benin & 197 & India & 2,722 & Peru & 1,208 \\
\hline Bhutan & 98 & Indonesia & 713 & Philippines & 716 \\
\hline Bolivia & 1,284 & Ireland & 501 & Poland & 1,829 \\
\hline Bosnia & 509 & Kazakhstan & 982 & Portugal & 505 \\
\hline Botswana & 444 & Kenya & 284 & Romania & 980 \\
\hline Brazil & 1,642 & Korea, Rep. of & 598 & Russia & 1,659 \\
\hline Bulgaria & 1,228 & Kosovo & 329 & Rwanda & 340 \\
\hline Burkina Faso & 51 & Kyrgyz Republic & 609 & Saudi Arabia & 681 \\
\hline Burundi & 407 & Lao PDR & 246 & Senegal & 262 \\
\hline Cambodia & 503 & Latvia & 547 & Serbia & 550 \\
\hline Cameroon & 119 & Lebanon & 354 & Slovakia & 528 \\
\hline Cape Verde & 47 & Lesotho & 75 & Slovenia & 536 \\
\hline Chile & 948 & Lithuania & 756 & South Africa & 603 \\
\hline China & 3,948 & Macedonia, FYR & 506 & Spain & 606 \\
\hline Colombia & 1,000 & Madagascar & 293 & Sri Lanka & 452 \\
\hline Costa Rica & 343 & Malawi & 160 & Swaziland & 429 \\
\hline Croatia & 550 & Malaysia & 902 & Syrian Arab Rep. & 560 \\
\hline Czech Republic & 760 & Mali & 155 & Tajikistan & 483 \\
\hline Dominican Republic & 250 & Mauritania & 361 & Tanzania & 760 \\
\hline Ecuador & 453 & Mauritius & 212 & Thailand & 1,385 \\
\hline Egypt & 1,973 & Mexico & 1,480 & Turkey & 2,544 \\
\hline El Salvador & 465 & Moldova & 766 & Uganda & 3,099 \\
\hline Eritrea & 79 & Mongolia & 195 & Ukraine & 5,004 \\
\hline Estonia & 521 & Montenegro & 100 & Uzbekistan & 660 \\
\hline Ethiopia & 427 & Morocco & 1,709 & Vietnam & 1,650 \\
\hline Gambia, The & 301 & Mozambique & 194 & Zambia & 207 \\
\hline Georgia & 374 & Namibia & 429 & & \\
\hline
\end{tabular}

Source: Authors' analysis based on World Bank Enterprise Surveys. 


\section{Table A2. Variable Definitions and Mean Statistics}

\begin{tabular}{|c|c|c|}
\hline Variable Name & Definition & Mean \\
\hline & Measures of Access to Finance & \\
\hline Bank Finance & $\begin{array}{l}\text { Dummy }(0 / 1)=1 \text { if the firm uses local or foreign bank finance } \\
\text { for working capital or new investment, and }=0 \text { otherwise. }\end{array}$ & 0.32 \\
\hline Leasing & $\begin{array}{l}\text { Dummy }(0 / 1)=1 \text { if the firm uses leasing for working capital or } \\
\text { new investment and }=0 \text { otherwise. }\end{array}$ & 0.7 \\
\hline Trade Credit & $\begin{array}{l}\text { Dummy }(0 / 1)=1 \text { if the firm uses trade credit for working capital } \\
\text { or new investment and }=0 \text { otherwise. }\end{array}$ & 0.27 \\
\hline Informal Finance & $\begin{array}{l}\text { Dummy }(0 / 1)=1 \text { if the firm uses informal finance or family and } \\
\text { friends for working capital or new investment and }=0 \\
\text { otherwise. }\end{array}$ & 0.14 \\
\hline Equity Finance & $\begin{array}{l}\text { Dummy }(0 / 1)=1 \text { if the firm uses new equity, grants, or 'other' } \\
\text { financing for working capital or new investment and }=0 \\
\text { otherwise. }\end{array}$ & 0.19 \\
\hline Retained Earnings & $\begin{array}{l}\text { Dummy }(0 / 1)=1 \text { if the firm uses retained earnings for } 100 \\
\text { percent of working capital and new investment financing and } \\
=0 \text { otherwise. }\end{array}$ & 0.20 \\
\hline \multirow[t]{2}{*}{$\begin{array}{l}\text { No External } \\
\text { Financing }\end{array}$} & $\begin{array}{l}\text { Dummy }(0 / 1)=1 \text { if the firm does not use any external financing } \\
\text { for working capital or new investment and }=0 \text { otherwise. } \\
\text { Survey responses suggest owners in many countries confused } \\
\text { equity and retained earnings, thus we do not consider new } \\
\text { equity to be external financing in defining this variable. }\end{array}$ & 0.39 \\
\hline & General Firm Chard & \\
\hline Firm Age & Continuous variable equal to firm age in years. & 16.08 \\
\hline Micro & $\begin{array}{l}\text { Dummy }(0 / 1)=1 \text { if the firm has less than } 10 \text { employees and }=0 \\
\text { otherwise. }\end{array}$ & 0.26 \\
\hline Small & $\begin{array}{l}\text { Dummy }(0 / 1)=1 \text { if the firm has } 10-49 \text { employees and }=0 \\
\text { otherwise. }\end{array}$ & 0.39 \\
\hline Med/Large & $\begin{array}{l}\text { Dummy }(0 / 1)=1 \text { if the firm has } 50 \text { or more employees and }=0 \\
\text { otherwise. (Excluded category). }\end{array}$ & 0.35 \\
\hline Exporter & $\begin{array}{l}\text { Dummy }(0 / 1)=1 \text { if the firm exports more than } 10 \text { percent of its } \\
\text { goods and }=0 \text { otherwise. }\end{array}$ & 0.23 \\
\hline Limited Liability & $\begin{array}{l}\text { Dummy }(0 / 1)=1 \text { if the firm is a publicly listed company or a } \\
\text { privately held, limited company and }=0 \text { otherwise. } \\
\text { (cooperatives, partnerships and sole-proprietors are the } \\
\text { excluded categories). }\end{array}$ & 0.48 \\
\hline Audit & $\begin{array}{l}\text { Dummy }(0 / 1)=1 \text { if the firm has audited financial statements and } \\
=0 \text { otherwise. }\end{array}$ & 0.53 \\
\hline Foreign Owned & $\begin{array}{l}\text { Dummy }(0 / 1)=1 \text { if the largest shareholder is a foreign company } \\
\text { and }=0 \text { otherwise. }\end{array}$ & 0.5 \\
\hline \multirow[t]{2}{*}{ State Owned } & $\begin{array}{l}\text { Dummy }(0 / 1)=1 \text { if the firm has state ownership and }=0 \\
\text { otherwise. }\end{array}$ & 0.4 \\
\hline & Country Characteristics & \\
\hline Low Income Group & $\begin{array}{l}\text { Dummy }(0 / 1)=1 \text { for countries with GNI per capita less than } \\
\$ 766 \text {, and zero otherwise (WB-WDI). }\end{array}$ & 0.37 \\
\hline $\begin{array}{l}\text { Lower-Middle } \\
\text { Income Group }\end{array}$ & $\begin{array}{l}\text { Dummy }(0 / 1)=1 \text { for countries with GNI per capita between } \\
\$ 766 \text { and } \$ 3,035 \text {, and zero otherwise (WB-WDI). }\end{array}$ & 0.36 \\
\hline
\end{tabular}


TABLE A2. Continued

\begin{tabular}{lcr}
\hline Variable Name & Definition & Mean \\
\hline Upper-Middle & $\begin{array}{c}\text { Dummy }(0 / 1)=1 \text { for countries with GNI per capita between } \\
\text { Income Group }\end{array}$ & 0.19 \\
$\begin{array}{l}\$ 3,036 \text { and } \$ 9,385, \text { and zero otherwise (WB-WDI). } \\
\text { High Income Group } \\
\text { Dummy }(0 / 1)=1 \text { for countries with GNI per capita in excess of } \\
\$ 9,385, \text { and zero otherwise (WB-WDI). }\end{array}$ & 0.8 \\
\hline
\end{tabular}

\section{REFERENCES}

Allen, Franklin, Rajesh Chakrabarti, Sankar De, Jun Qian, and Meijun Qian. 2006. "Financing Firms in India.” World Bank Policy Research Working Paper No. 3975. Washington, D.C.

Ayyagari, Meghana, Asli Demirgüc-Kunt, and Vojislav Maksimovic. 2010. "Formal versus Informal Finance: Evidence from China." Review of Financial Studies 23 (8): 3048-3097.

Baldwin, John R., Guy Gellatly, and Valérie Gaudreault. 2002. "Financing innovation in new small firms: new evidence from Canada." Statistics Canada analytical studies series. Working Paper No. 190.

Beck, Thorsten, Asli Demirguc-Kunt, and Vojislav Maksimovic. 2005. "Financial and Legal Constraints to Firm Growth: Does Firm Size Matter?" Journal of Finance 60 (1): 137-177.

Beck, Thorsten, Asli Demirguc-Kunt, and Vojislav Maksimovic. 2008. "Financing Patterns around the World: Are Small Firms Different?" Journal of Financial Economics 89 (3): 467-487.

Brealey, Richard A., and Stewart C. Myers. 2003. Financing and Risk Management. New York: McGraw-Hill.

Brown, Gregory, Larry Chavis, and Leora Klapper. 2008. "A New Lease on Life: Institutions, External Financing, and Business Growth.” World Bank Policy Research Working Paper. Washington, D.C.

Bulan, Laarni, and Zhipeng Yan. 2009. "The Pecking Order of Financing in the Firm's Life Cycle." Banking and Financing Letters 1 (3): 129-140.

Carpenter, Robert E., and Laura Rondi. 2000. "Italian Corporate Governance, Investment, and Finance." Emperica 27 (4): 365-388.

Djankov, Simeon, Ira Lieberman, Joyita Mukherjee, and Tatiana Nenova. 2002. "Going Informal: Benefits and Costs." In Boyon Belev, ed., The Informal Economy in the EU Accession Countries. Sofia: Center for the Study of Democracy, 63-80.

Evans, David S, and Boyan Jovanovic. 1989. "An Estimated Model of Entrepreneurial Choice under Liquidity Constraints." Journal of Political Economy 97 (4): 808-27.

Klapper, Leora, Luc Laeven, and Raghu Rajan. 2006. "Barriers to Entrepreneurship.” Journal of Financial Economics 82(3): 613-641.

Levine, R. 2005. "Finance and Growth: Theory and Evidence." In Philippe Aghion and Steven Durlauf, eds., Handbook of Economic Growth. Amsterdam: Elsevier Science.

Mehnaz, Safavia, and Joshua Wimpey. 2007. "When Do Enterprises Prefer Informal Credit?” World Bank Policy Research Working Paper No. 4435. Washington, D.C.

Müller, Elisabeth, and Volker Zimmermann. 2009. "The Importance of Equity Finance for R\&D." Small Business Economics 33 (3): 303-318.

Myers, Stewart, and Nicholal S. Majluf. 1984. "Corporate Financing and Investment Decisions when Firms have Information that Investors Do Not Have." Journal of Financial Economics 33 (3): 187-221.

Paulson, Anna L., and Robert Townsend. 2004. "Entrepreneurship and financial constraints in Thailand." Journal of Corporate Finance 10 (2): 229-262.

Shirai, Sayuri. 2009. "Banks' Lending Behavior and Firms' Corporate Financing Patterns in People's Republic of China." Keio University, Faculty of Policy Management Working Paper. Tokyo.

Schumpeter, Josef. 1942. Capitalism, Socialism and Democracy. New York: Hampers and Brothers. 